\title{
Intergenerational Morphostructural Stability and Harmony of Marin Magellan Meat Merino Ewes
}

\author{
Estabilidad y Armonía Intergeneracional Morfoestructural de Ovejas Marin Magellan Meat Merino
}

\author{
R. de la Barra*; M. E. Martínez*; C. Calderón*** \& E. Latorre**
}

DE LA BARRA, R.; MARTínEZ, M. E.; CALDERÓN, C. \& LATORRE, E. Intergenerational morphostructural stability and harmony of marin magellan. Int. J. Morphol., 31(4):1455-1458, 2013.

SUMMARY: The aim of this study was to evaluate the stability and harmony of the morphostructural format of the Marin Magellan Meat Merino breed in order to contribute to knowledge about the differentiation of sheep populations. In summer 2010, evaluation on a sheep population coming from an incomplete absorbent crossbreeding of Corriedale by Australian Merino breeds was done in Magallanes Region, Chile. All three and five year-old ewes (62 and 50, respectively) were measured. Fourteen body measurements were taken and nine body indexes were calculated. Results show that the evaluated sheep population does not show significant intergenerational differences in most of the morphostructural variables. At the same time, there is a high between-age similarity in the correlations between zoometric indexes. Therefore, it can be stated that the morphostructural model of Marin Magellan Meat Merino ewes shows a high degree of stability and harmony.

KEY WORDS: Sheep; Genetic crossbreeding; Morphology; Morphostructural stability.

\section{INTRODUCCIÓN}

The census of Chilean sheep livestock indicates that there is about two and a half million head of sheep. Most of this animal stock corresponds to Corriedale breed, which hold a marked aptitude to the production of medium-fineness wool. Value addition to production has led many producers to a crossbreeding process with Merino breed, in order to produce a finer wool withhigher commercial value (Bianchi et al., 2006; Cardellino \& Müeller, 2008). One of the most widespread crossbreedings has been the absorption of Corriedale by Australian Merino, process that, in many cases, has not been complete, leading to the appearance of animal populations which differ from the breeds on which the crossbreeding was based, and favoring the appearance of a new genetic resource. In this regard, the characterization of the morphological attributes is the first step for the management of a genetic resource (Azor et al., 2008; Traoré et al., 2008; Duchev \& Groeneveld, 2006; Salako, 2006). By characterizing the animal population resulting from the incomplete absorbent crossbreeding of Corriedale by Australian Merino, it was evidenced a significant morphostructural differentiation in relation to the breeds that originated the crossbreeding, with a high degree of homogeneity within the population itself (Latorre et al., 2011); this allowed the official registration of a new breed, the Marin Magellan Meat Merino, and the opening of the respective genealogical register (Sánchez et al., 2011).

The definition of a breed clearly involves the differentiation of this new population from others, and at the same time, a delimited variability among the members of the population itself (Sierra, 2001; Herrera \& Luque, 2009). Nevertheless, when the new breed is the result of a crossbreeding process, is essential to determine if the morphostructural format keep its characteristics from one generation to the next, as it depends that the characteristic attributes of the population are sustained over time (Herrera et al., 1996; Legaz et al., 2011).

Therefore, the aim of this study was to evaluate the stability and harmony of the morphostructural format of the Marin Magellan Meat Merino breed in order to contribute to the knowledge about the differentiation of this sheep population.

\footnotetext{
Instituto de Investigaciones Agropecuarias (INIA), Centro Experimental Butalcura, Chiloé, Chile.

** Instituto de Investigaciones Agropecuarias (INIA), Centro Regional Kampenaike, Magallanes, Chile.

This work was founded by the "Plan Genético Ovino" Proyect (Code FIC-CS-C-2006-P-001-376687 ) of Fundación para la Innovación Agraria (FIA), Chile.
} 


\section{MATERIAL AND METHOD}

In summer 2012, an aleatory sampling was carried out on 900 Marin Magellan Meat Merino ewes. As mentioned, this sheep breed is the product of an incomplete absorbing crossing of Corriedale by Australian Merino breeds (Latorre et al.).

Population sample size was estimated following the method proposed by Canon \& Roe

Where: $\quad$ Sample Size $=1 /\left(\frac{1}{n_{1}}+\frac{1}{P o p}\right)$

Pop $=$ is the population size

And $\quad n_{1}=\frac{4 p q}{L^{2}}$

Being p proportion of individuals in the population which are expected to be of the new incomplete absorbed crossing.

$$
\text { And } \mathrm{q}=1-\mathrm{p} \quad \mathrm{L}=\text { accepted error. }
$$

It was assumed that $85 \%$ of the animals in the population belonged to Magellan Meat Merino breed, despite not being registered yet in the official genealogical register. Accepted error was 5\%, and therefore sample size was estimated on 200 randomly selected ewes. All three and five year-old ewes from this sample (62 and 50, respectively) were measured. Fourteen body measurements were recorded, following the suggestions and protocols of Herrera et al., Álvarez et al. (2000), Calderón et al. (2009), Herrera \& Luque and Bravo \& Sepúlveda (2010). Body measurements were: Face Length (FL), Cranial Length (CraL), Cranial Width (CraW), Head Width (HW), Chest Width (ChW), Thorax Perimeter (ThP), Back Length (BaL), Rump Width (RW), Rump Length (RL), Thigh Lenght (TL), Body Depth (BD), Thorax Width (TW), Body Length (BoL), Withers Height (WH) and Rump Height (RH).

In addition, nine indexes were calculated from body measurements. These indexes were: Body Index (BI), Cephalic Index (CI), Cranial Index (CraI), Facial Index (FI), Thoracic Index (ThI), Thorax Relative Depth Index (TRDI), Ilium-Ischium Index (II), Longitudinal IliumIschium Index (LII), Transversal Ilium-Ischium Index
(TII), Metacarpal Thoracic Index (MTI) and Metacarpal RibIndex (MRI). Indexes were calculated following the recommendations of Salako and Bravo \& Sepúlveda.

The differences between the two age groups were assessed by the T-Student test, comparing body measurement means. The morphostructural format stability was evaluated by comparing the correlations between the zoometric indexes, calculated by means of a Pearson matrix estimated for each age group. Data were stored in an Excel electronic spreadsheet and analyzed by means of the Xlstat 2011 software.

\section{RESULTS AND DISCUSSION}

In the process of creation of Magellan Meat Merino Breed, the original (absorbed) breed was Corriedale, while the absorbing breed was Australian Merino. This crossbreeding was stopped and stabilized at an intermediate stage before the total absorption of Corriedale, leading to the appearance of a kind of animal which was different from the original breeds, with a degree of intra-population variability similar to that of recognized sheep breeds (Latorre et al.). Nevertheless, the conformation of an animal population as a new racial group requires the determination of the degree of the morphostructural format stability, in such a way that it shows a minimal variation and a similar general harmony in different generations.

Table I shows that there are no significant differences $(\mathrm{P}>0.05)$ between three and five-year-old ewes for most of the morphological variables evaluated, mainly in those of ethnological relevance (FL, CraL, CraW, HW, RW and RH). Significant differences (P < 0.05 ) can be observed only in the size of the thoracic area ( $\mathrm{ChW}$ and $\mathrm{ThP}$ ). The reason could be that the breeds involved in the absorbent crossbreeding are very different in terms of its thoracic format, so it is expected that the stabilization process of this trait will be slower. In this sense, it can be assessed that sheep resulting from this process show an advanced degree of intergenerational stability, but still in process of maturation.

Relating to indexes, in our study there are 21 coincident and 4 non- coincident significant correlations between the two age groups (Table II). CrI shows four coincident significant correlations: - 0.404 (3 years) and 0.499 ( 5 years) between CrI and TRDI; - 0.423 ( 3 years) and -0.542 ( 5 years) between CrI and FII; -0.800 ( 3 years) and -0.682 ( 5 years) between CrI and MTII, and - 0.443 (3 
Table I. Means $(\mathrm{cm})$, difference $(\mathrm{cm})$ and statistic significance $(\mathrm{T}$ test) for the differences in body measurements between three and five year-old Marin Magellan Meat Merino ewes.

\begin{tabular}{lccc}
\hline $\begin{array}{l}\text { Biometric } \\
\text { variables }\end{array}$ & $\begin{array}{c}\text { 3 year-old } \\
\text { sheep (a) }\end{array}$ & $\begin{array}{c}\text { 5 year-old } \\
\text { sheep (b) }\end{array}$ & $\begin{array}{c}\text { Difference } \\
\text { (a-b) }\end{array}$ \\
\hline FL & 18.62 & 18.68 & -0.06 \\
CraL & 7.27 & 7.27 & 0.00 \\
CraW & 7.57 & 7.20 & 0.37 \\
HW & 12.15 & 12.17 & -0.02 \\
ChW & 22.17 & 22.77 & $-0.60^{*}$ \\
ThP & 85.75 & 89.95 & $-4.20^{*}$ \\
BaL & 38.00 & 37.14 & 0.86 \\
RW & 12.20 & 11.85 & 0.35 \\
RL & 13.53 & 12.84 & 0.70 \\
TL & 26.26 & 26.00 & 0.26 \\
BD & 30.75 & 31.16 & -0.42 \\
TW & 22.17 & 23.11 & -0.94 \\
BoL & 70.28 & 71.63 & -1.35 \\
WH & 68.24 & 70.05 & -1.81 \\
RH & 69.64 & 71.35 & -1.71 \\
\hline P $<0.05$ & & &
\end{tabular}

years) and -0.382 ( 5 years) between CrI and MRI. FI shows coincident significant correlations in all cases between the two ages. There are also a coincident significant correlation between FI and CI: 0.681 ( 3 years) and 0.495 (5 years). ThI shows a coincident significant correlation with BI between the two age groups: -0.568 ( 3 years) and -0.437 (5 years). TRDI shows a coincident significant correlation with BI between the two age groups: -0.336 ( 3 years) and -0.412 (5 years). For LII, there are coincident significant correlations with BI and II: -0.347 ( 3 years) and -0.441 ( 5 years) in the first case, and -0.425 ( 3 years) and -0.477 ( 5 years) in the second. TII shows three coincident significant correlations between ages. For TII and TRDI, 0.567 (3 years) and 0.518 ( 5 years); for TII and II, 0.518 ( 3 years) and 0.611 ( 5 years), and for TII and LII 0.544 ( 3 years) and 0.484 (5 years). MTI shows coincident significant correlations with BI: 0.629(3 years) and 0.665 (5years); with FI: 0.395 ( 3 years) and 0.479 (5 years), with TRDI: 0.409 ( 3 years) and -0.378 (5 years), with II:-0.419 (3 years) and -0.359 ( 5 years) and with TII: -0.452 ( 3 years) and -0.378 (5 years). MRI shows coincident significant correlations with BI: 0.614 ( 3 years) and 0.513 (5 years); with ThI: -0.710 ( 3 years) and -0.639 (5 years); with TRDI -0.488 ( 3 years) and -0.456 ( 5 years), with II: -0.460 ( 3 years) and -0.536 ( 5 years), and with MTI: 0.713 ( 3 years) and 0.693 (5 years).

The four discordances between ages were found for II with TRDI, TII with BI, MTI with TII and MRI with TII. Therefore, there is a similar harmony in the body format of both generations. This reaffirms the idea that the incomplete absorbent crossbreeding which lead to the appearance of Marin Magellan Meat Merino breed has reached the stability in the morphostructural format, and therefore the productive abilities ascribed to this format remain the same between generations (Zaitoun et al., 2005; Yakubu et al., 2010). This way, morphostructural stability is expressed as a desirable and defining characteristic of this animal breed's definition (Sierra; Herrera \& Luque).

\section{ACKNOWLEDGMENTS}

The authors wish to acknowledge to Mr. José Marín Antonín and to Ganadera Marín's technical staff for their facilities and support on the process of data collection. The authors are also grateful to Consorcio Ovino S.A. for their cooperation in funding the research work.

Table II. Pearson's correlation matrix of zoometric indexes of three year-old (above diagonal) and five year-old (below diagonal) Marin Magellan Meat Merino ewes.

\begin{tabular}{lccccccccccc}
\hline Indexes & BI & CI & CraI & FI & ThI & TRDI & II & LII & TII & MTI & MRI \\
\hline BI & 1 & -0.037 & $-0.404^{*}$ & 0.224 & $-0.568^{*}$ & $-0.336^{*}$ & -0.103 & $-0.347^{*}$ & $-0.406^{*}$ & $0.629^{*}$ & $0.614^{*}$ \\
CI & -0.199 & 1 & 0.077 & $0.681^{*}$ & 0.302 & -0.069 & 0.004 & 0.153 & 0.143 & 0.011 & -0.161 \\
CraI & $-0.499^{*}$ & 0.477 & 1 & $-0.423^{*}$ & -0.035 & 0.230 & 0.209 & 0.035 & 0.209 & $-0.800^{*}$ & $-0.443^{*}$ \\
FI & -0.254 & $0.495^{*}$ & $-0.542^{*}$ & 1 & 0.109 & -0.234 & 0.027 & 0.084 & 0.126 & $0.395^{*}$ & 0.234 \\
ThI & $-0.437^{*}$ & -0.100 & -0.120 & -0.020 & 1 & 0.165 & 0.162 & 0.154 & 0.280 & -0.174 & $-0.710^{*}$ \\
TRDI & $-0.412^{*}$ & 0.248 & 0.177 & 0.124 & 0.340 & 1 & $0.491^{*}$ & 0.164 & $0.567^{*}$ & $-0.409^{*}$ & $-0.488^{*}$ \\
II & 0.307 & -0.175 & 0.046 & -0.143 & -0.358 & 0.449 & 1 & $-0.425^{*}$ & $0.518^{*}$ & $-0.419^{*}$ & $-0.460^{*}$ \\
LII & $-0.414^{*}$ & 0.253 & 0.359 & 0.273 & 0.330 & 0.289 & $-0.477^{*}$ & 1 & $0.544^{*}$ & -0.087 & -0.069 \\
TII & -0.313 & 0.169 & 0.309 & 0.104 & -0.217 & $0.518^{*}$ & $0.611^{*}$ & $0.484^{*}$ & 1 & $-0.452^{*}$ & $-0.472^{*}$ \\
MTI & $0.665^{*}$ & -0.078 & $-0.682^{*}$ & $0.479^{*}$ & 0.013 & $-0.378^{*}$ & $-0.359^{*}$ & 0.186 & -0.352 & 1 & $0.713^{*}$ \\
MRI & $0.513^{*}$ & -0.113 & $-0.382^{*}$ & -0.071 & $-0.639^{*}$ & $-0.456^{*}$ & $-0.536^{*}$ & -0.254 & -0.412 & $0.693^{*}$ & 1 \\
\hline
\end{tabular}

$* \mathrm{P}<0.05$ 
DE LA BARRA, R.; MARTÍNEZ, M. E.; CALDERÓN, C. \& LATORRE, E. Estabilidad y armonía intergeneracional morfoestructural de ovejas marin magellan meat merino. Int. J. Morphol., 31(4):1455-1458, 2013.

RESUMEN: El objetivo de este estudio fue evaluar la estabilidad y la armonía del formato morfoestructural de la raza ovina Marin Magellan Meat Merino en la Región de Magallanes (Chile), con el fin de contribuir al conocimiento de la diferenciación de las poblaciones ovinas. En el verano de 2010 se evaluó esta nueva raza, que es producto de un cruzamiento absorbente incompleto de Corriedale por Merino Australiano. Se midieron todas las hembras de tres y cinco años (62 y 50, respectivamente). Se tomaron catorce mediciones corporales y se calcularon nueve índices. Los resultados indican que la población ovina evaluada no muestra diferencias intergeneracionales significativas en la mayor parte de las variables morfoestructurales estudiadas. Al mismo tiempo, hay una gran similitud entre edades respecto a las correlaciones entre índices zoométricos. Por lo tanto, se puede afirmar que el modelo morfoestructural de las ovejas Marin Magellan Meat Merino evidencia un alto grado de estabilidad y armonía.

PALABRAS CLAVE: Oveja; Cruzamiento genético; Morfología; Estabilidad morfoestructural.

\section{REFERENCES}

Álvarez, S.; Fresno, M.; Capote, J.; Delgado, J. \& Barba, C. Estudio para la caracterización de la raza ovina Canaria. Arch. Zootec., 49:209-15, 2000

Azor, P. J.; Goyache, F. \& Gutiérrez, J. P. Métodos genéticos y estadísticos de diferenciación entre poblaciones. En: Junta de Andalucía (Ed.). La ganadería andaluza en el siglo XXI. Vol. III. Patrimonio ganadero Andaluz, 2008. pp.169-84.

Bianchi, G.; Garibotto, G.; Betancur, O.; Feed, O. \& Franco, J. Efecto del peso al sacrificio sobre la calidad de la canal y de la carne de cordero puros y en cruza. Arch. Med. Vet., 38(2):161-5, 2006.

Bravo, S. \& Sepúlveda, N. Índices zoométricos en ovinos criollos Araucanos. Int. J. Morphol., 28(2):489-95, 2010.

Calderón, C.; De la Barra, R.; Martínez, M. E. \& Gonzalo, C. Variabilidad fenotípica morfoestructural de las razas ovinas predominantes en Chiloé. VII Simposio de recursos genéticos para América latina y el Caribe (SIRGEALC), Pucón, Chile, 2009. pp.1578.

Cardellino, R. \& Müeller, J. Fibre production and sheep breeding in South America. Proc. Assoc. Advmt. Breed. Genet., 18:366-73, 2008.

Duchev, Z. \& Groeneveld, D. Improving the monitoring of animal genetic resources on National or International level. Arch. Tierz., 49:532-44, 2006.

Herrera, M.; Rodero, E.; Gutiérrez, M.; Peña, F. \& Rodero, J. Application of multifactorial discriminant analysis in the morphostructural differentiation of Andalusian caprine breeds. Small Ruinant Res., 22:39-47, 1996.

Herrera, M. \& Luque, M. Morfoestructura y sistemas para el futuro en la valoración morfológica. En: Valoración Morfológica de los animales domésticos. Sañudo, A. C. (Ed.). Madrid, Ministerio de Medio Ambiente y Medio Rural y Marino, 2009.

Latorre, E.; Uribe, H.; Martínez, M. E.; Calderón, C. \& De la Barra, R. Morphological differentiation and structural functionality of ewes due to incomplete crosssbreeding. Int. J. Morphol., 29(3):954-9, 2011.
Legaz, E.; Cervantes, I.; Pérez-Cabal, M.; De la Fuente, F.; Martínez, R.; Goyache, F. \& Gutiérrez, J. Multivariate characterisation of morphological traits in Assaf (Assaf. E) sheep. Small Ruminant Res., 100(2):122-30, 2011.

Salako, A. Application of morphological indexes in the assessment of type and function in sheep. Int. J. Morphol., 24(1):13-8, 2006.

Sánchez, P.; De la Barra, R.; Calderón, C., García, J. \& Rodriguez, J. Comparación de caracteres cuantitativos de la lana en carneros pertenecientes a las razas Corriedale, Marin Magellan Meat Merino y Merino Australiano. XXXVI Congreso de la Sociedad Chilena de Producción animal, 36:29-30, 2011.

Sierra, I. El concepto de raza: evolución y realidad. Arch. Zootec., 50(192):547-64, 2001.

Traoré, A.; Tamboura, H. H.; Kaboré, A.; Royo, L. J.; Fernández, I.; Álvarez, I.; Sangaré, M.; Bouchel, D.; Poivey, J. P.; Francois, D.; Toguyeni, A.; Sawadogo, L. \& Goyache, F. Multivariate characterization of morphological traits in Burkina Faso sheep. Small Ruminant Res., 80:62-7, 2008.

Yakubu, A.; Salako, A. E.; Imumorin, I. G.; Ige, A. O. \& Akinyemi, M. O. Discriminant analysis of morphometric differentiation in the West African Dwarf and Red Sokoto goats. S. Afr. J. Anim. Sci., 40:381-7, 2010.

Zaitoun, I.; Tabbaa, M. \& Bdour, S. Differentiation of native goat breeds of Jordan on the basis of morphostructural characteristics. Small Ruminant Res., 56(1-3):173-82, 2005.

Correspondence to:

M. E. Martínez

Instituto de Investigaciones Agropecuarias (INIA)

Centro Regional Kampenaike

Magallanes - CHILE

Email: mariae.martinez@inia.c

Received: 11-08-2012

Accepted: 11-10-2013 